\title{
„MASZYNKA DO GŁOSOWANIA”. LEGITYMIZOWANIE DECYZJI RZĄDU JAKO GŁÓWNA FUNKCJA PARLAMENTU
}

Przedmiotem mojego zainteresowania jest empirycznie ustalona rola parlamentu w procesie stanowienia prawa. Opieram się na wynikach projektu badawczego $^{1}$, zrealizowanego z zastosowaniem złożonej metodologii ${ }^{2} \mathrm{w}$ latach 2011-2014. Uzyskane wyniki pozwalają na postawienie tezy, że w rzeczywistości proces ustawodawczy jest w całości kontrolowany przez rząd. Dotyczy to zarówno uchwalania przez Sejm całych ustaw, jak i przyjmowania poprawek w toku procesu legislacyjnego. Wyniki te są podobne dla obu izb, a obserwacja prac wybranych komisji sejmowych i senackich pozwala twierdzić, że rząd kontroluje proces ustawodawczy również w komisjach.

Kontrola władzy wykonawczej nad procesem ustawodawczym determinowana jest czynnikami instytucjonalnymi, w szczególności sposobem wyłaniania władzy ustawodawczej i wykonawczej, który sprzyja podporządkowaniu parlamentu i rządu jednemu ośrodkowi decyzyjnemu, którym jest rządząca partia polityczna, dysponująca większością parlamentarną. W VII kadencji Sejmu i VIII kadencji Senatu, podczas których prowadzono badania, dodatkowym czynnikiem sprzyjającym rządowej kontroli nad procesem legislacyjnym była relatywna stabilność parlamentarnego zaplecza rządu.

W wyniku przeprowadzonych badań stwierdzono: (1) bardzo wysoką skuteczność legislacyjną przedłożeń rządowych, (2) bardzo wysoką spójność wewnątrz-

1 Projekt „Socjologiczna analiza procesu legislacyjnego w świetle wybranych tez teorii systemów Niklasa Luhmanna”, sfinansowany ze środków Narodowego Centrum Nauki, przyznanych na podstawie decyzji numer DEC-2011/01/D/HS6/02386.

2 Wykorzystano gotowe dane urzędowe, zarówno jakościowe (stenogramy i inne dokumenty), jak i ilościowe (dane z głosowań oraz dane dotyczące projektów ustaw - ich liczby, autora, czasu procedowania i innych cech). Analizowano stenogramy z posiedzeń Sejmu i Senatu oraz czterech wybranych komisji (2 sejmowe i 2 senackie) od początku kadencji w listopadzie 2011 do końca 2012 roku. Dane z głosowań w Sejmie i Senacie pozyskano dla okresu od początku kadencji do końca 2012 roku, a dla 4 wybranych komisji - dla okresu prowadzenia obserwacji. Dodatkowo przeprowadzono systematyczną obserwację prac 4 wybranych komisji sejmowych i senackich (łącznie 113 posiedzeń w okresie od 15.02.2012 do 31.12.2012 roku). Analiza zebranych danych obejmowała ilościową analizę treści 106 protokołów z posiedzeń plenarnych i posiedzeń komisji, dotyczących 25 projektów ustaw, analizę statystyczną głosowań (współczynnik spójności Rice’a, wzorce) oraz wniesionych projektów ustaw, a także jakościową analizę stenogramów i danych obserwacyjnych. Pełne wyniki przedstawiono w książce A. Dudzińska, System zamknięty. Socjologiczna analiza procesu legislacyjnego. Warszawa 2015. 
klubową w głosowaniach we wszystkich klubach, przy czym najwyższa spójność została stwierdzona w klubie głównej partii rządzącej, (3) zwyczaj uzyskiwania dla każdej poprawki aprobaty rządu, (4) rozpowszechnienie zjawiska przeprowadzania projektów rządowych ścieżką poselską, (5) silne utożsamianie się posłów rządzącej partii z rządem, (6) rytualny charakter debaty parlamentarnej.

W zakresie efektywności legislacyjnej dla analizowanej, dobiegającej końca VII kadencji Sejmu uchwalone według stanu na dzień 15 maja 2015 r. projekty stanowiły 54\% spośród wszystkich złożonych 1143 projektów, zaś projekty wycofane lub odrzucone $-13 \%$. Pozostałe projekty były w trakcie procedowania. Odnotowano jednak bardzo duże różnice między wskaźnikiem uchwalonych na ten moment projektów pomiędzy różnymi ich autorami. Najwyższą wartość (89\%) osiągnął wskaźnik efektywności legislacyjnej dla projektów rządowych, istotnie niższą - dla projektów komisyjnych $(65 \%)$ i senackich $(61 \%)$, a jeszcze niższą dla prezydenckich (48\%), poselskich (31\%) i obywatelskich (8\%). Na podstawie doświadczeń z poprzedniej kadencji ${ }^{3}$, a także dokładniejszej analizy przeprowadzonej dla wszystkich projektów rządowych złożonych w roku $2012^{4}$ można oczekiwać, że do końca kadencji wskaźnik efektywności legislacyjnej projektów rządowych zbliży się do $100 \%$. Świadczy to o silnej pozycji rządu w zakresie inicjatywy ustawodawczej oraz o skutecznym przeprowadzaniu projektów rządowych z wykorzystaniem większościowego zaplecza parlamentarnego.

Warunkiem skuteczności legislacyjnej rządu jest wysoki stopień spójności w sposobie głosowania klubów rządzącej koalicji. Spójność badano za pomocą indeksu Rice'a, którego liczbowa formuła oznacza bezwzględną różnicę między proporcją danej grupy głosującą „,za" a proporcją tej grupy głosującą „przeciw”. Ponieważ wartość 1 oznacza doskonałą zgodność w sposobie głosowania, zatem im bardziej wartość indeksu zbliża się do 1 , tym większa zgodność (spójność). W przypadku głosowań w Sejmie wartość indeksu spójności była najwyższa dla PO $(0,99)$ i dla PSL $(0,97)$, natomiast dla klubów opozycyjnych wyniosła od 0,83 dla Ruchu Palikota, poprzez 0,87 dla PiS, 0,89 dla Solidarnej Polski aż do 0,95 dla SLD. Niższe wartości dla opozycji wynikają z mniej sprawczego charakteru oddawanych przez nią głosów. Natomiast bardzo wysokie wartości dla klubów rządzącej koalicji, zwłaszcza PO, dowodzą istnienia dyscypliny partyjnej, umożliwiającej rządowi prowadzenie skutecznej polityki na poziomie ustawodawstwa. Warto w tym miejscu podkreślić, że wysoka dyscyplina cechowała klub PO także w głosowaniach w Senacie $(0,99)$ i w badanych czterech komisjach sejmowych i senackich $(0,96)$. Uzyskane wyniki są potwierdzeniem wniosków z badań ankietowych, przeprowadzonych

3 Zob. M. Żuralska (red.), Analiza działalności ustawodawczej Sejmu VI kadencji, Warszawa 2012, s. 63.

$4 \quad$ Zob. A. Dudzińska, System zamknięty. Socjologiczna analiza procesu legislacyjnego, Warszawa 2015, s. 70-71 (przypis).

$5 \quad$ Indeks przybiera wartości od 0 do 1 . Wartość 1 oznacza, że wszyscy głosowali za lub wszyscy głosowali przeciw. Wartość 0 oznacza sytuację, gdy głosy za i przeciw rozłożyły się pół na pół. Wartość 0,5 natomiast oznacza sytuację, gdy głosów za jest dwukrotnie mniej lub dwukrotnie więcej niż głosów przeciw. 
wśród posłów VI kadencji, opisanych w publikacji pod red. prof. Marii Kruk ${ }^{6}$. Badania te wykazały, że ,posłami najbardziej poddawanymi partyjnym naciskom są posłowie PO"'.

Kolejne zaobserwowane zjawisko to dobrze ugruntowany zwyczaj uzyskiwania opinii rządu dla każdej ze zgłaszanych w komisjach poprawek. Jego istnienie stwierdzono w toku bezpośredniej obserwacji prac w wybranych komisjach ${ }^{8}$, prowadzonej w roku 2012, a także na podstawie stenogramów z posiedzeń tych komisji. Warto podkreślić, że o ile przepisy regulują sposób postępowania z rządowymi projektami ustaw, w tym autopoprawkami i poprawkami do tych projektów ${ }^{9}$, a także sposób formułowania stanowiska rządu do pozarządowego projektu ustawy ${ }^{10}$, to opiniowanie przez przedstawiciela rządu każdej poprawki do każdego pozarządowego projektu ustawy nie jest wymagane przepisami. Co więcej, M. Mistygacz uważa, że „z racji równouprawnienia podmiotów mających prawo inicjatywy ustawodawczej regulaminowe uprzywilejowanie pozycji rządu w procesie ustawodawczym nosiłoby znamiona niekonstytucyjności, Rada Ministrów na żadnym etapie postępowania sejmowego nie może w sposób władczy oddziaływać na zgłaszane poprawki." ${ }^{11}$ Mimo to $\mathrm{z}$ przeprowadzonych obserwacji wynika, że zwyczaj uzyskiwania akceptacji rządu jest stosowany w odniesieniu do wszystkich poprawek, a co więcej, wyrażona opinia traktowana jest jako wiążąca dla większości parlamentarnej, stanowiącej zaplecze rządu. Można zatem mówić o niesformalizowanej samorzutnej racjonalizacji procesu ustawodawczego.

Dodatkowo zaobserwowano przypadki przejmowania poprawek rządowych przez posłów, mimo iż zgodnie z art. 119 ust. 2 Konstytucji RP prawo do wnoszenia poprawek do projektu w czasie rozpatrywania go przez Sejm przysługuje wnioskodawcy, posłom i Radzie Ministrów. Poprawki rządowe bywały przejmowane przez posłów nawet, gdy dotyczyły projektu rządowego. Do takiej sytuacji doszło na 17. posiedzeniu sejmowej Komisji Gospodarki, podczas którego procedowano rządowy projekt ustawy o zmianie ustawy o obrocie z zagranicą towarami, technologiami i usługami o znaczeniu strategicznym dla bezpieczeństwa państwa, a także dla utrzymania międzynarodowego pokoju i bezpieczeństwa oraz o zmianie niektórych innych ustaw, z druku nr 229. Oto jak przewodniczący komisji przedstawia posłom sprawę poprawek, w tym poprawek rządowych:

„Wśród szeregu poprawek, które omówiliśmy na posiedzeniu podkomisji, jednak nie znalazły się poprawki, które zostały zgłoszone przez rząd i które właśnie w tej chwili mamy przed sobą. (...) Biorąc pod uwagę to, że jest 6 nowych poprawek

M. Kruk (red.), Mandat przedstawicielski w teorii, prawie i praktyce poselskiej, Warszawa 2013.

Ibidem, s. 249.

Sejmowe Komisja Gospodarki i Komisja Spraw Zagranicznych, senackie Komisja Gospodarki Narodowej i Komisja Spraw Zagranicznych.

9 Uchwała nr 190 Rady Ministrów z dnia 29 października 2013 r. - Regulamin pracy Rady Ministrów (M.P. poz. 979).

10 Ibidem, dział IV rozdział 6.

11 M. Mistygacz, Rząd w procesie ustawodawczym w Polsce, Warszawa 2012, s. 252. 
rządu, myślę, że dla uzupełnienia, te wszystkie nowe poprawki, czyli 2 poprawki Izby Przedsiębiorców na rzecz Obronności Kraju, jak również 6 poprawek rządowych, będziemy mogli przyjąć na tym posiedzeniu. Oczywiście te poprawki będziemy omawiać i posłowie będą mogli je po prostu przejąć." (pos. 17. sejmowej Komisji Gospodarki).

W rezultacie posłanka PO, będąca jednocześnie przewodniczącą podkomisji nadzwyczajnej do spraw tej ustawy, przejęła i zgłosiła wszystkie poprawki rządowe. Niestety ustalenie faktycznego autora poprawek wymaga uważnej lektury stenogramów, a niekiedy nawet ona nie prowadzi do trafnych ustaleń. Kładzie to cień na przejrzystości procesu ustawodawczego.

Kolejnym przejawem dominacji rządu nad parlamentem jest zjawisko „bypassowania" projektów rządowych, czyli zgłaszania ich jako projekty poselskie przez posłów klubów koalicyjnych. Jak wiadomo, w stosunku do projektów rządowych obowiązują szczególne zasady ich przygotowywania, określone w Regulaminie prac Rady Ministrów. Z ich przedłożeniem wiąże się zatem szereg działań, jakie muszą być podjęte na etapie przedparlamentarnym: opracowanie i przyjęcie założeń projektu ustawy, opracowanie projektów podstawowych aktów wykonawczych i oceny skutków regulacji, a następnie uzgodnienia, opiniowanie i konsultacje. Projekt trafia następnie na komitet stały Rady Ministrów, do Rządowego Centrum Legislacji i wreszcie może zostać wniesiony pod obrady rządu. Procedura ta postrzegana jest jako uciążliwa i czasochłonna, dlatego rząd wykorzystuje często ścieżkę poselską. W stenogramach sejmowych można znaleźć wypowiedzi, które potwierdzają taką praktykę:

„Nie jest to ustawa wielce skomplikowana. Wydaje mi się też, że sama ustawa była napisana gdzieś tam, w ministerstwie, jak to często się zdarza, i przekazana posłom jednego z klubów koalicyjnych. (...) Ja rozumiem, takie rzeczy się robi, bo na przykład ktoś się zagapił, są terminy, a wiadomo, że są jeszcze konsultacje międzyresortowe, a to trwa itd. Wtedy rząd w porozumieniu z koalicją umawia się: dobrze, to przepchniemy to przez posłów. (...) Wiem, że jego nie należy używać, ale czasami w każdym rządzie trzeba." (pos. 41. sejmowej Komisji Gospodarki).

Takie „pójście na łatwiznę” jest o tyle godne ubolewania, że to właśnie rządowe projekty ustaw, w tym procedury ich uzasadniania, oceny skutków oraz konsultowania, wyznaczają właściwe standardy legislacyjne. Na ten walor rządowej procedury legislacyjnej zwraca uwagę m.in. A. Bałaban: ,może ona w swych elementach (...) być traktowana jako wzorcowa dla wszelkich innych struktur organizacyjnych przygotowujących projekty aktów normatywnych."12

Inny autor, M. Mistygacz, uważa zgłaszanie inicjatyw ustawodawczych przez posłów tworzących większość parlamentarną za ,,sprzeczne z logiką systemu parla- 
mentarno-gabinetowego. Wynika to z przyjęcia założenia, że rząd będący emanacją większości parlamentarnej realizuje program wyborczy, którego konsekwencją jest program prac legislacyjnych. Program rządu wyznacza cele strategiczne, a inicjatywy ustawodawcze stanowią narzędzie jego realizacji." 13

Wydaje się zatem, że zaobserwowane zjawisko „bypassowania” projektów rządowych przemawia na rzecz wprowadzenia stosownych zmian.

Potwierdzeniem zlewania się władzy ustawodawczej i wykonawczej jest też zaobserwowane wypowiadanie się parlamentarzystów koalicji, zwłaszcza rządzącej PO, zamiast przedstawicieli rządu, do których np. kierowane są pytania. Oto krótki, ale jaskrawy przykład takiego zlewania się ról:

„Poseł Tadeusz Iwiński (SLD):

- Chciałem zapytać przedstawicieli rządu, dlaczego Polska wchodzi do ESA później niż Rumunia?

Przewodniczący poseł Grzegorz Schetyna (PO):

- Bo Rumunia weszła wcześniej niż Polska. Dziękuję, zamykam posiedzenie.”

(wspólne posiedzenie sejmowych komisji Spraw Zagranicznych i Gospodarki).

Ostatni wskaźnik świadczący o słabości parlamentu stanowi fikcja debaty parlamentarnej. Jej przejawy to między innymi absencja na posiedzeniach plenarnych, znaczna fluktuacja uczestników posiedzeń komisji, zajmowanie się podczas posiedzeń innymi rzeczami, podpisywanie list obecności bez uczestniczenia w posiedzeniu, głosowanie przez konsensus, problemy z uzyskaniem kworum w głosowaniach na posiedzeniach komisji, a także odnotowany w wyniku analizy treści niski udział realnej debaty merytorycznej. ${ }^{14}$

Zaobserwowane zjawiska każą postawić pytanie o faktyczną realizację w Polsce konstytucyjnej zasady podziału władz. Zależność władzy ustawodawczej od rządu nie tylko stoi w sprzeczności z tą zasadą, ale wykracza także poza zasadę równowagi, zapisaną w tym samym artykule 10 Konstytucji i taktowaną jako druga - obok zasady podziału władz - subzasada obecna w tym artykule. ${ }^{15}$ Zależność parlamentu od rządu uniemożliwia też realne sprawowanie przez Sejm funkcji kontrolnej nad działalnością Rady Ministrów (art. 95 Konstytucji).

Zasada podziału i równowagi władz ma przede wszystkim związek z zasadą władzy zwierzchniej narodu. Doniosłe znaczenie tego związku podkreślają np. J. Ku-

13 M. Mistygacz, Rząd w procesie ustawodawczym w Polsce, Warszawa 2012, s. 363-364.

14 Dokładniejsze omówienie poczynionych obserwacji można znaleźć w publikacji książkowej: A. Dudzińska, System zamknięty..., op. cit.

15 J. Kuciński, W.J. Wołpiuk, Zasady ustroju politycznego państwa w Konstytucji Rzeczypospolitej Polskiej z 1997 roku, Warszawa 2012, s. 303. 
ciński i J.W Wołpiuk. ${ }^{16}$ Stojąc na stanowisku, iż organy każdej z władz bezpośrednio wyrażają wolę narodu w zakresie funkcji spełnianych przez daną władzę i zauważając, że podział władzy sprzyja także zachowaniu jedności władzy w rękach suwerena, autorzy ci przywołują jednocześnie zasadę pluralizmu politycznego. Daje ona różnym orientacjom politycznym możliwość efektywnego wpływania na sprawowanie władzy państwowej. Podział władz sprzyja takiemu pluralizmowi, nie naruszając jedności. ${ }^{17}$

Oczywiście, jak zauważa L. Garlicki, ,zasada podziału władz nie ma charakteru absolutnego. Jej podstawową treścią jest odrzucenie możliwości skumulowania całej władzy w rękach jednego podmiotu." 18 Także Kuciński i Wołpiuk w przywoływanej pracy stawiają kluczowe pytanie o cel podziału władz. Ich zdaniem, jest nim „dążenie do wypracowania takiego modelu ustrojowego, który najskuteczniej chroniłby wolność jednostki, zapobiegał despotyzmowi i ograniczeniom owej wolności." ${ }^{19}$ Powołują się dalej na wyrok Trybunału Konstytucyjnego z 1992 roku (U 6/92, OTK ZU 1992, nr 13), który wśród celów zasady podziału władz na pierwszym miejscu wymienił ochronę praw obywatelskich, a w innym orzeczeniu (K 11/93) jako sposób realizacji tej ochrony wskazał ,uniemożliwienie nadużycia władzy przez którykolwiek ze sprawujących ją organów". ${ }^{20}$ Jeśli zatem nadmierna koncentracja władzy państwowej może grozić nadużyciami, to dane uzyskane w toku badań należy uznać za sygnał ostrzegawczy.

Odnosząc się do funkcjonalnego aspektu podziału władz, Kuciński i Wołpiuk dostrzegają niezwykle istotny czynnik, jakim jest polityczny charakter zarówno legislatywy, jak i egzekutywy. Autorzy ci podkreślają, że ,rola odgrywana przez partie polityczne zmienia, a nawet «rozmywa» tradycyjny funkcjonalny podział władzy między legislatywą a egzekutywą. W rzeczywistości bowiem podmiotem rozstrzygającym o treści uchwalanych ustaw i kierunkach polityki państwa jest partia polityczna (lub koalicja) posiadająca większość w parlamencie (zwłaszcza w Sejmie) i formująca Radę Ministrów. Trudno jest więc mówić o podziale władzy w sensie politycznym między legislatywą a egzekutywą, gdy Rada Ministrów jest politycznie identyczna z większością parlamentarną. Polityczna jednolitość Rady Ministrów i sejmowej większości rządzącej kształtuje się niejako «w poprzek» zasady podziału i równowagi władz, co pociąga za sobą istotne konsekwencje ustrojowe.”21 Cytowani autorzy poprzestają jednak na tej konkluzji.

$16 \quad$ Ibidem, s. 299.

17 Ibidem, s. 300-302.

18 L. Garlicki, Polskie prawo konstytucyjne. Zarys wykładu, Warszawa 2014, s. 73.

19 J. Kuciński, W.J. Wołpiuk, Zasady ustroju politycznego państwa w Konstytucji Rzeczypospolitej Polskiej z 1997 roku, Warszawa 2012, s. 303.

20 Ibidem, s. 303-304.

21 J. Kuciński, W.J. Wołpiuk, Zasady ustroju politycznego państwa w Konstytucji Rzeczypospolitej Polskiej z 1997 roku, Warszawa 2012, s. 313. 
Natomiast problem zaradzenia zmniejszaniu się roli parlamentu, które wynika między innymi z upartyjnienia zarówno legislatywy, jak i egzekutywy, podejmuje A. Bierć. Uważa on, że ważnym środkiem łagodzącym ów „deficyt demokracji” mogą stać się odpowiednio prowadzone konsultacje publiczne i inne mechanizmy zwiększania obywatelskiej partycypacji w procesie stanowienia prawa. ${ }^{22} \mathrm{Wskazanie}$ na związek między zmniejszeniem się roli parlamentu, będącego przecież podstawową instytucjonalną emanacją suwerena, a zwiększeniem partycypacji obywatelskiej w procesie legislacyjnym rzuca nowe światło na wyniki przeprowadzonych badań. Świadczą one bowiem o niebezpieczeństwie równoległego zmniejszenia roli legislatywy i podporządkowania jej rządowi oraz zamykania procesu legislacyjnego na głos społeczeństwa obywatelskiego, wyrażającego istotne zbiorowe potrzeby suwerena. ${ }^{23}$

Można tym samym stwierdzić, że postulowane przez niektórych konstytucjonalistów rozwiązania ustrojowe już obecnie funkcjonują w rzeczywistości na mocy zwyczaju. Ich sformalizowanie polegałoby na ,zagwarantowaniu rządowi środków pozwalających mu przeforsować rozwiązania prawodawcze zgodne z wyznaczonymi przezeń kierunkami polityki państwa", w tym prawa do selekcji poprawek. ${ }^{24}$

\section{BIBLIOGRAFIA}

Bałaban Andrzej. 2003. Polskie problemy ustrojowe (konstytucja, źródła prawa, samorząd terytorialny, prawa człowieka). Kantor Wydawniczy Zakamycze.

Banaszak Bogusław. 2013. Jakie zmiany w Konstytucji RP są potrzebne? W Aktualne problemy reform konstytucyjnych, 17-40. Białystok: Temida 2.

Bierć Andrzej. 2006. Racjonalna procedura prawodawcza. W Prawo w XXI wieku. Księga pamiątkowa 50-lecia Instytutu Nauk Prawnych Polskiej Akademii Nauk, 85-105. Warszawa: Wydawnictwo Naukowe Scholar.

Dudzińska Agnieszka. 2015. System zamknięty. Socjologiczna analiza procesu legislacyjnego. Warszawa: Instytut Studiów Politycznych PAN i Wydawnictwo Naukowe Scholar.

Garlicki Leszek. 2014. Polskie prawo konstytucyjne. Zarys wykładu. Warszawa: LexisNexis.

Kruk Maria (red. nauk). 2013. Mandat przedstawicielski w teorii, prawie i praktyce poselskiej. Warszawa: Wydawnictwo Sejmowe.

22 A. Bierć, Racjonalna procedura prawodawcza jako podstawa dobrego prawa, (w:) W. Czapliński (red.), Prawo w XXI wieku. Księga pamiątkowa 50-lecia Instytutu Nauk Prawnych Polskiej Akademii Nauk, Warszawa 2006, s. 94. Konieczność zwiększenia instytucjonalnej partycypacji społeczeństwa w procesie ustawodawczym dostrzega też B. Banaszak (B. Banaszak, Jakie zmiany w Konstytucji RP są potrzebne?, (w:) S. Bożyk, Aktualne problemy reform konstytucyjnych, Białystok 2013, s. 30).

23 W książce „System zamknięty. Socjologiczna analiza procesu legislacyjnego” wskazuję na stosowane przez system polityczny sposoby neutralizowania wpływu zewnętrznego i radzenia sobie z ,intruzami”.

24 R. Puchta, Czy Konstytucja wymaga naprawy? O propozycjach zmian ustawy zasadniczej, (w:) M. Zubik (red.) XV lat obowiązywania Konstytucji z 1997 r., Warszawa 2012, s. 237-238. W podobnym duchu wypowiada się M. Mistygacz, Rola rządu w procesie ustawodawczym (w systemie parlamentarnym), (w:) T. Mołdawa, J. Szymanek, M. Mistygacz (red.), Parlamentarny system rządów, Warszawa 2012, s. 295. 
Kuciński Jerzy, Waldemar J. Wołpiuk. 2012. Zasady ustroju politycznego państwa w Konstytucji Rzeczypospolitej Polskiej z 1997 roku. Warszawa: LEX a Wolters Kluwer business.

Mistygacz Michał. 2012. Rząd w procesie ustawodawczym w Polsce. Warszawa: Instytut Nauk Politycznych, Uniwersytet Warszawski.

Mistygacz Michał. 2012. Rola rządu w procesie ustawodawczym (w systemie parlamentarnym). W Parlamentarny system rządów, 282-295. Warszawa: Dom Wydawniczy ELIPSA.

Puchta Radosław. 2012. Czy Konstytucja wymaga naprawy? O propozycjach zmian ustawy zasadniczej. W XV lat obowiązywania Konstytucji z 1997 r., 225-255. Warszawa: Wydawnictwo Sejmowe.

Żuralska Marta (red.). 2012. Analiza działalności ustawodawczej Sejmu VI kadencji. Warszawa: Koło Naukowe Analizy Prawa „Ratio Legis”, Uniwersytet Warszawski. 
"VOTING MACHINE". LEGITIMIZATION OF GOVERNMENT DECISIONS AS THE MAIN FUNCTION OF PARLIAMENT

The paper discusses the role of parliament in the legislative process, as empirically determined in a research project in the years 2011-14. The results show that in fact the legislative process is fully controlled by the government. The results are similar for both chambers and their committees.

The results demonstrate: (1) high legislative effectiveness of bills initiated by the government, (2) high intra-party voting cohesion (Rice index), especially for the main ruling party, (3) requiring government approval for any amendment, (4) "by-passing" procedural requirements for the bills initiated by the government and presenting them instead as bills initiated by MPs, (5) merging the role of MP and the role of a member of the governing party, (6) ritual character of parliamentary debate.

This evidence challenges the constitutional rule of separation of powers and proves that despite formal regulations and theoretical proposals, the government actually executes quite strong informal control over legislation via party mechanisms.

Keywords: constitution, separation of powers, parliament, government, legislation

Słowa kluczowe: konstytucja, podział władz, parlament, rząd, legislacja 